\title{
Key Audit Matters and Investors' Reactions
}

\author{
Nor 'Asyiqin Abu's , Romlah Jaffar', Mohd Mohid Rahmat', \\ and Mohamat Sabri Hassan ${ }^{2}$ \\ ${ }^{1}$ Faculty of Accountancy, Universiti Teknologi MARA Melaka \\ ${ }^{2}$ Faculty of Economics and Management, Universiti Kebangsaan Malaysia
}

\begin{abstract}
The new requirement of International Standards on Auditing (ISA) 701 specifies that auditors must highlight key audit matters (KAMs) found in the financial statements audit of listed companies commencing in December 2016. As proposed by standard setters, KAMs are considered crucial to be highlighted to shareholders due to the clarity that KAMs provide regarding audited financial statements. However, findings from various countries indicate that there are mixed investors' reactions to KAMs. Therefore, this study examined the relationship between KAM disclosure and investors' reactions among 931 firm-year observations on Malaysian Public Listed Companies from 2016 to 2019. The number of KAMs, new matters in KAMs, and recurring KAMs were the independent variables, whereas the share price served as a dependent variable to represent investors' reactions. The results of ordinary least squares (OLS) and fixed effect regression indicated that KAMs do not affect share prices, even when they interact with going concern opinions. Additionally, the findings indicated that investors' reactions were mostly prompted by a company's financial performance and governing characteristics rather than by KAMs. The findings contribute to the literature on KAMs and investors' reactions, especially in the Malaysian context.
\end{abstract}

Keywords: Key Audit Matters, Enhanced Audit Report, Investors' Reactions, Share Price

\section{ARTICLE INFO}

\section{Article History:}

Received: 19 June 2021

Accepted: 05 November 2021

Available online: 01 December 2021

\footnotetext{
* Corresponding Author: Nor 'Asyiqin Abu, Faculty of Accountancy Universiti Teknologi MARA Cawangan Melaka, 78000 Melaka, Malaysia; Email: norasyiqin@uitm.edu.my; Tel: +606-558-2143.
} 


\section{INTRODUCTION}

The International Auditing and Assurance Standards Board (IAASB) issued the ISA 701 Communicating Key Audit Matters in the Independent Auditor's Report to enhance the communicative value of the auditor's report by providing greater transparency about the audit performed. Key Audit Matters (KAMs) are intended to provide additional information to users of financial statements and assist users in understanding significant matters in the audited financial statements of the current period. Communicating KAMs may also help users understand the entity and areas of significant management judgement in the audited financial statements (ISA 701: Para 2). The IAASB's requirement to communicate KAMs has become effective for audits of financial statements for periods ending on or after 15 December 2016 for public listed companies.

KAMs disclosure will increase the amount of information available to investors, allowing them to make better informed decisions (Velte, 2019). Christensen et al. (2014) were among the first to demonstrate that the disclosure of KAMs may influence the decisions of users of financial statements. They conducted an experiment among U.S. business school graduates representing non-professional investors and found that investors who received a KAMs-like paragraph regarding the uncertainty of management estimates were more likely to stop investing in a company compared to investors who received a standard audit report.

However, previous studies on investors' reactions documented mixed evidence. Some studies found KAMs relevant to investors due to KAMs' influence on abnormal returns and abnormal trading volumes (Fayad Altawalbeh \& Alhajaya, 2019; Reid et al., 2015). On the other hand, Boonyanet and Promsen (2019) and Gutierrez et al. (2018) found no evidence that the new rule on the auditor's report has a significant effect on investors' reactions. Their findings implied that there is little information in the audit report, even with the inclusion of KAMs. This scenario is contrary to the expectation of standards setters such as the IAASB that KAMs should be informative to investors and other important stakeholders.

Since 15 December 2016, the Malaysian Institute of Accountants (MIA) has required auditors to comply with the ISA 701 when auditing 
Malaysian public listed companies. Several studies have been conducted in this country since then. Nasir (2019) examined the characteristics of KAMs and how they are reported. The findings indicated that KAMs were reported in a generic manner. However, the disclosure of KAMs significantly varied between unqualified and qualified audit reports. Additionally, Abu and Jaffar (2020) investigated the effect of independent, financial experts and audit committee meetings on KAMs. The findings indicated that only companies with frequent audit committee meetings were able to reduce the number of KAMs. It is apparent that, while research on KAMs is increasing globally, the study of Malaysia's analysis of KAM effects are still limited. To enrich the current international understanding on the outcome of KAMs, this study evaluated Malaysian investors' reactions to the disclosure of the information contained in the KAMs. Specially, this study investigated the association between disclosure of KAMs and investors' reactions.

The content of this paper is arranged as follows. The following section discusses the Signalling Theory (ST) as the theoretical foundation for this research, the literature on auditor's reports and investors' reactions, KAMs and the development of the main hypothesis. It is followed by the research design, descriptive statistics, and the results of regression analysis. The conclusion section includes a summary, limitations, and future studies that could be expanded from this paper.

\section{LITERATURE REVIEW AND HYPOTHESIS DEVELOPMENT}

\section{Signalling Theory}

The ST proposed by Akerlof(1970) discusses how to solve imbalanced information among parties involved in a business transaction. Signalling to investors can be done by issuing an audit report containing the auditor's opinion about the reasonableness of a company's financial statements (Hay \& Cordery, 2018). Auditors' report can mitigate the level of information asymmetry and improve the relationship between shareholders and managers (Hearn, 2013). Even, assurance from the independent auditors will reduce managements' incentives to make overly optimistic disclosures in financial statements of companies (Ittonen, 2012). Such assurance boosts 
the confidence of investors and other users of financial statements on the reliability of a company's financial reports. The expanded auditors' report via disclosure of KAMs requires empirical investigation to determine whether it can effectively communicate valuable information to investors.

\section{Auditor's Report and Investors' Reactions}

The audit report presents the auditor's opinion as to whether the financial statement of a company is true and fair, and is consistent with generally accepted accounting principles (GAAP) (ISA 200: Para 3). A non-qualified or an unmodified audit report will increase the credibility of the financial statement, as it indicates that the organisation has properly complied with all the accounting standards (Abad \& Yagüe, 2017). In contrast, a qualified or modified audit opinion is the way the auditors communicate their concerns about the quality of a company's financial statement or their inability to collect adequate and appropriate evidence (Abad \& Yagüe, 2017). The type of audit opinion can affect investors' interpretation of financial information and one way of determining whether the auditors' statements are insightful or not is through market reaction (Lennox et al., 2015).

There are two primary reasons for investors' reactions (Ittonen, 2012). First, the audit report may contain information that affects either the estimation or the riskiness of future cash flows. Second, the audit report may include substantial information about the viability of a company, especially through the going concern opinion (GCO). The GCO is one of the most studied forms of audit explanatory language. It states that the auditor has substantial doubt about a company's ability to continue as a going concern. Menon and Williams (2010) found a negative abnormal return of approximately $6 \%$ in the three-day window following the initial disclosure of a GCO, leading to the conclusion that going concern audit reports provide useful information about company distress to investors.

Ianniello and Galloppo (2015) examined investors' reactions to qualified and unqualified audit reports in Italy. They found that qualified audit reports had a negative effect on stock prices, while unqualified reports had the opposite effect. Hsu et al. (2011) examined stock price reactions following the release of qualified auditor's reports in Taiwan. A sample of 
106 Taiwanese public shareholding companies were analysed for the period 1999-2009, and the findings revealed the occurrences of unusual negative returns during the first five days after the issuance of qualified reports, suggesting substantial impacts on investors' decisions.

\section{Key Audit Matters}

In Malaysia, the ISA 701: Communicating Key Audit Matters in the Independent Auditor's Report must be adopted for the audit of the financial statements of public listed companies (PLCs) for periods ending on or after 15 December 2016. The ISA 701 defines KAMs as:

"Those matters that, in the auditor's professional judgment, were of most significance in the audit of the financial statements of the current period. Key audit matters are selected from matters communicated with those charged with governance"

(ISA 701: Para 8)

The introduction of the ISA 701 is expected to provide relevant and useful information to the capital market, minimise uncertainty regarding company performance, and encourage understanding of financial statements (Securities Commission Malaysia, 2018). The expanded auditor's report, which incorporates disclosure of KAMs is aimed to provide additional information to shareholders (Porumb et al., 2018). Reid et al. (2015) suggested that insights from the auditors could build greater public trust and confidence in the entire financial reporting process. Therefore, it seems plausible that the KAMs highlighted in the auditor's report could provide new and useful information to investors that would aid in investment decisions or cause investors to react.

KAMs' reporting in the auditor's report contains information about significant management judgment, significant accounting estimates, and high estimation of uncertainty. Consistent with the ST, more information made available to the public, will reduce information asymmetry between management and users of financial statements. However, there is no conclusive finding whether KAMs will signal important communicative value of the audit report and cause investors to react since the results are mixed across countries. 
Bédard et al. (2019) investigated the effects of the Justifications of Assessment (JOAs) in France. JOAs, which are similar to KAMs, have been made mandatory since 2003 . The results revealed higher abnormal trading volumes in the first year after the introduction of the JOAs but not in the following years. The study found that investors reacted only after the JOAs were first mandated. Further, investor reactions measured by abnormal trading volumes occurred only in small companies, indicating that the JOAs were associated with increased information for smaller companies as they are characterised by a weaker information environment.

The UK Financial Reporting Council (FRC) introduced the disclosure rules on significant risk of material misstatement (RMM) in the audit reports of London Stock Exchange (LSE) companies effective from 1 October 2012 before KAMs came into practice. Gutierrez et al. (2018) collected data on RMM adopters and non-adopters for two years before and after the rules were introduced. They then implemented a difference-in-difference research design to determine whether the new reporting standard had different effects on adopters and non-adopters. They measured market reactions using abnormal returns and found no evidence that RMM had enhanced the information environment for adopters compared to non-adopters moving from the pre- to the post-adoption period.

In the context of the Asian region, Boonyanet and Promsen (2019) used stock price as a dependent variable to measure investors' response to the inclusion of KAMs in audit reports. The samples included the common stocks of the top 100 Thai listed companies (SET 100) on the Stock Exchange of Thailand. Their findings showed that even though KAMs had little informative value to investors, KAMs relating to the provision for doubtful debt had a positive and significant relationship with stock prices. Fayad Altawalbeh and Alhajaya (2019) compiled and evaluated a total of 195 audit reports for the companies listed on the Amman Stock Exchange (ASE) in 2016 to determine Jordanian external auditors' practices in disclosure of KAMs. The results showed that the disclosure of KAMs significantly affected investors' decisions measured by abnormal trading volumes and suggested that the mandating of disclosure of KAMs had an informational value for investors. 
The disclosure of KAMs would result in a lower expectation gap for risk-neutral and risk-seeking investors (Velte \& Issa, 2019). Expectation gap reduces as investors are better informed about the nature of external audits. Expectation gap is the difference in the level of assurance between what is expected by investors and what is provided by auditors. Due to a lower expectation gap, risk-neutral and risk-seeking investors will appreciate the transparency provided by KAMs with regard to capital investment (Velte \& Issa, 2019). In Thailand, investors respond positively and stock prices rose when the auditor's report included KAMs (Boonyanet \& Promsen, 2019). KAMs were also found to be correlated with higher abnormal trading volumes and lower abnormal bid-ask spreads, indicating reductions in information asymmetries between auditors and audit report users (Reid et al., 2015; Fayad Altawalbeh \& Alhajaya, 2019).

On the contrary, the disclosure of more KAMs would increase the perceived audit risk and might cause risk-averse investors to leave the company (Velte \& Issa, 2019). Audit risk is the risk that financial statements are materially incorrect despite the audit opinion stating that the financial reports are free of any material misstatements. Based on an experimental study conducted by Christensen et al. (2014) in the U.S., the presence of Critical Audit Matters (CAMs) in the audit report discourages investors from investing. A study even found that users had a lower confidence in financial statements with CAMs than in financial statements without CAMs (Kachelmeier et al., 2019). The authors also warned that the disclosure of CAMs may act as a warning that the financial statements should be carefully interpreted.

In addition to the positive and negative reactions expected from KAMs disclosure, Pelzer (2016) highlighted other concerns, such as a lack of investor education about KAMs and misunderstanding about auditors' functions. Investors do not appear to receive adequate communications from auditors because they do not understand the message or information delivered through KAMs. According to Pelzer (2016), audit committees and auditors should be worried that the disclosure of KAMs information could have detrimental consequences due to a lack of awareness and education.

This study anticipated the information value of disclosure of KAMs since KAMs convey information about a material account that requires 
complex auditor judgement and estimation. KAMs disclosure also conveys uncertainty and acknowledges the inherent difficulty auditors face in providing assurance for the related material account. Given that prior research has revealed both positive and negative reactions to disclosure of KAMs the following hypothesis was tested:

Hypothesis: There is an association between disclosure of KAMs and investors' reactions.

\section{METHODOLOGY}

The population of this study consisted of 919 Malaysian public listed companies as at May 2020. Companies categorised in Finance, REITS, and Closed-End Fund sectors, totalling 55 were dropped due to their unique characteristics and business operations as well as different rules and regulatory requirements. The proportionate stratified random sampling method was used to categorise the companies into their respective industry, and then companies were drawn at random from each industry. Krejcie and Morgan (1970) and Sekaran and Bougie (2016) suggested using a sample size of 269 for a population of approximately 900 . This study determined the number of samples from each industry based on the number of companies in the strata over the total population $\times 269$. Table 1 shows the number of samples from each industry.

This study covered four annual reporting periods from 2016 to 2019 since the ISA 701 became effective in Malaysia in 2016. Companies with fiscal year ends in December had four years of observation, while companies with fiscal year ends in other months had only three years of observation since their first year of ISA 701 implementation was 2017. Table 1 shows the results of the final observations. Data on KAMs were collected from the annual reports of companies while data on share prices and the control variables were obtained from the Thomson Reuters DataStream Professional (DataStream). 
Table 1: Sample Selection

Panel A: Industry Composition

\begin{tabular}{lcc}
\hline \multicolumn{1}{c}{ Industry } & $\begin{array}{c}\text { Number of } \\
\text { Companies }\end{array}$ & $\begin{array}{c}\text { Proportionate } \\
\text { Sampling }\end{array}$ \\
\hline Industrial Products \& Services & 258 & 80 \\
Consumer Products \&Services & 191 & 59 \\
Technology, Telecommunication \& Media & 124 & 39 \\
Property & 97 & 30 \\
Construction & 54 & 17 \\
Energy \& Utilities & 44 & 14 \\
Plantation & 44 & 14 \\
Transportation \& Logistic & 35 & 11 \\
Health Care & 17 & 5 \\
TOTAL & 864 & 269 \\
\hline
\end{tabular}

Panel B: Number of Observations

Financial year end

Number of Companies

Observations

\begin{tabular}{lcc}
\hline December (2016-2019) & 140 & 560 \\
Other than December (2017-2019) & 129 & 387 \\
Unavailable annual report & & $(7)$ \\
Unavailable market capitalization data & & $(2)$ \\
Qualified and Disclaimer opinion with no KAMs & $(1)$ & $(7)$ \\
TOTAL & 268 & 931 \\
\hline
\end{tabular}

This study used share price as the dependent variable to determine investors' reactions to KAMs. According to Ohlson (1995), financial information is value relevant if it has a significant association with market values such as share price. Share price changes rapidly due to investors' reactions to new publicly available information, which is relevant for investors in forming their expectations of the future performance of a company. Share price provides information on how shareholders and investors evaluate a company's performance (Gitman, 2009). Most researchers estimated that the value relevance of reported financial information for a given financial year is within 3 to 4 months after the financial year end, corresponding with the period of earnings announcement ( Easton \& Harris, 1991; Tahinakis \& Samarinas, 2016). Paragraph 9.23(1) of the Main Market Listing Requirements of Bursa Malaysia specifies that a listed company must issue its annual report and audited financial statements 
and related documents within four months after the end of its financial year. Thus, this study incorporated the share prices of the companies for four months after the closing date of each financial year to ensure that investors had access to the information in the auditor's reports. Eleven control variables, year, and industry were included to assess their potential confounding effects on the share prices. Table 2 presents a summary of the variables used, the definitions of the variables, and the expected sign of the effect of each variable.

Table 2: Summary of Variables and Their Descriptions

\begin{tabular}{|c|c|c|c|}
\hline Variables & Descriptions & Symbol & $\begin{array}{l}\text { Expected } \\
\text { Sign }\end{array}$ \\
\hline \multicolumn{4}{|c|}{ Independent Variables } \\
\hline Number of KAMs & $\begin{array}{l}\text { Total Number of Matters Mentioned in } \\
\text { KAMs' Section }\end{array}$ & NUM_KAMs & \\
\hline The New Matters & $\begin{array}{l}\text { The New Matters in the KAMs' Section of } \\
\text { the Current Year }\end{array}$ & $N E W_{-}$KAMs & \\
\hline Recurrning KAMs & $\begin{array}{l}\text { The Matters Reported in Current Year and } \\
\text { in Prior Year }\end{array}$ & $R E_{-} K A M s$ & \\
\hline \multicolumn{4}{|l|}{ Control Variables } \\
\hline $\begin{array}{l}\text { Book Value Per } \\
\text { Share }\end{array}$ & $\begin{array}{l}\text { Total Shareholders' Equity/Number of } \\
\text { Shares Outstanding }\end{array}$ & $B V S$ & $(+)$ \\
\hline Return on Equity & Net Income / Shareholders Equity & $R O E$ & $(+)$ \\
\hline $\begin{array}{l}\text { Earnings Per } \\
\text { Share }\end{array}$ & $\begin{array}{l}\text { Net Income/Number of Shares } \\
\text { Outstanding }\end{array}$ & EPS & $(+)$ \\
\hline Dividend Per Share & $\begin{array}{l}\text { Dividends Paid/Number of Shares } \\
\text { Outstanding }\end{array}$ & DPS & $(+)$ \\
\hline Dividend Yield & Dividend Per Share/ Price Per Share & $D Y$ & $(+)$ \\
\hline Price earnings & Stock price/ EPS & $P E$ & $(+)$ \\
\hline Firm Size & $\begin{array}{l}\text { Natural Log of Market Capitalization at the } \\
\text { End of the Year }\end{array}$ & SIZE & $(+)$ \\
\hline Leverage & $\begin{array}{l}\text { Company's Total Debt Divided by Total } \\
\text { Assets }\end{array}$ & LEV & $(-)$ \\
\hline Board Size & $\begin{array}{l}1 \text { if the Number of Board Members Is } \\
\text { Within } 6-8,0 \text { Otherwise }\end{array}$ & $B D S I Z E$ & $(+)$ \\
\hline Board Independent & $\begin{array}{l}1 \text { if the Proportion of Independent Board } \\
>0.5,0 \text { Otherwise }\end{array}$ & $B D I N D$ & $(+)$ \\
\hline Audit Firm Size & $\begin{array}{l}1 \text { if the Company is Audited by Big } 4 \text { Audit } \\
\text { Firm, } 0 \text { Otherwise }\end{array}$ & BIG4 & $(+)$ \\
\hline \multicolumn{4}{|l|}{ Dependent Variable } \\
\hline Share Price & $\begin{array}{l}\text { Share Price of a Company at } 4 \text { Months } \\
\text { After Financial Year-End }\end{array}$ & PRICE & \\
\hline
\end{tabular}


This study incorporated firm-specific characteristics, corporate governance, and audit quality in the empirical model due to their influence on the share prices of companies. Sharif et al. (2015) suggested that a higher book value per share depicts sound financial performance of a company as book value is a major representation of owners' funds. Thus, a higher book value affects stock prices positively. Nirmala et al. (2011) revealed that dividend, price-earnings ratio, and leverage are major determinants of share prices for all the sectors in India. Khan et al. (2011) analysed the impact of dividend policy on stock prices in Malaysia after controlling for factors such as earnings per share, profit after tax, and return on equity. The results revealed that dividend yield, earnings per share, and return on equity were positively related to stock prices. Leverage is another important determinant of share prices and it suggests that investors attach more value to firms that have less debt as increased debt minimises stakeholders' earnings. Stakeholders also prefer firms with higher earnings per share due to the potentially higher returns from investments in such firms. Firm size was also a significant determinant of share prices in Bahrain (Sharif et al., 2015). Prior studies suggest that board size and board independence are linked with firms' values (Rahmat et al., 2020).

The hypothesis developed in the previous section were tested using multiple regression analysis using the following model:

$$
\begin{aligned}
\text { PRICE }= & \beta_{\mathrm{o}}+\beta_{1} N U M_{-} K A M_{i t}+\beta_{2} N E W_{-} K A M_{i t}+\beta_{3} R E-K A M_{i t} \\
& +\beta_{4} B V S+\beta_{5} R O E_{i t}+\beta_{6} E P S+\beta_{7} D P S_{i t}+\beta_{8} D Y+\beta_{9} P E_{i t} \\
& +\beta_{10} S I Z E_{i t}+\beta_{11} L E V+\beta_{12} B D S I Z E+\beta_{13} B D I N D_{i t}+ \\
& \beta_{14} B I G 4+\delta_{1-\mathrm{n}} \text { Industry effects }+\theta_{1-\mathrm{n}} \text { Year effects }+\varepsilon_{i t}
\end{aligned}
$$

\section{RESULTS AND DISCUSSION}

The number of KAMs disclosed by companies in each industry is tabulated in Table 3. The auditor's reports contained a maximum of six KAMs each, all of which were from companies in the Industrial Product \& Services and Technology, Telecommunications, and Media sectors. There were also zero KAM observations in the Technology, Telecommunications, and Media industry. KAMs disclosure contained one or two issues in almost 70\% (653) of the observations. Three KAMs disclosure appeared in 20\% (192) of the 
observations, and four and five disclosures appeared in the remaining $10 \%$ (75) of the observations.

Table 3: Tabulation of Industry and Number of KAMs

\begin{tabular}{lcccccccc}
\hline \multicolumn{1}{c}{ Industry } & \multicolumn{7}{c}{ Number of KAMs } \\
\hline & 0 & 1 & 2 & 3 & 4 & 5 & 6 & Total \\
Industrial Products \& Services & & 105 & 107 & 57 & 7 & 2 & 2 & 280 \\
Consumer Products \&Services & & 75 & 72 & 32 & 21 & 4 & & 204 \\
Technology, Telecommunication \& Media & 6 & 37 & 40 & 30 & 14 & 4 & 3 & 134 \\
Property & & 26 & 44 & 25 & 5 & & & 100 \\
Construction & & 15 & 27 & 14 & 3 & 3 & & 62 \\
Energy \& Utilities & 9 & 18 & 12 & 4 & 3 & & 46 \\
Plantation & & 19 & 17 & 11 & 4 & & & 51 \\
Transportation \& Logistics & & 7 & 22 & 9 & & & 38 \\
Health Care & & 8 & 5 & 2 & 1 & & & 16 \\
\hline Total observation & 6 & 301 & 352 & 192 & 59 & 16 & 5 & 931 \\
\hline
\end{tabular}

Table 4 shows the types of issues disclosed in the KAMs section of the companies reviewed in this study. Revenue recognition was the most common issue appearing in the KAMs disclosure with $33 \%$ of the observations. Nasir (2019) found revenue recognition a common issue in both unqualified and qualified auditor's reports. Revenue recognition is a candidate for inclusion in the KAMs of most audited companies as fraud involving revenue recognition is likely to be a topic of discussion between the auditor and audit committee (KPMG, 2017). In this study, revenue recognition was a significant issue in KAMs with 309 observations.

Trade receivables came in second due to their values that represented considerable portions of companies' overall assets. Furthermore, impairment losses of trade receivables require management judgement based on specific criteria such as the debt's age, the existence of disputes, recent past payment patterns, and any other accessible information about counterparties' creditworthiness. Given the magnitudes and judgements involved, trade receivables are considered a KAM in an audit. Moreover, effective 1 January 2018, companies must recognise an allowance for trade receivables impairment loss based on a new forward-looking expected credit loss approach under MFRS 9, Financial Instruments. This new approach requires management to use significant judgements and estimates when making assumptions about the risk of default, the timeframe of debt collection, 
and the inputs to the impairment calculation. The auditor's judgement and significant attention during the audit are necessary to assess the propriety and appropriateness of management's estimated credit loss impairment model.

Thirdly, inventories create a considerable audit risk since they can be held for a long time before being sold, rendering them vulnerable to obsolescence or theft. If the cost is greater than the net realisable value, the inventory value may be overstated. Thus, substantial management judgement is required when evaluating inventory provisions. Besides, the costing of inventories in manufacturing organisations demands an audit of management's costing technique and a recalculation of the costing to determine the accuracy of the inventory valuation. Moreover, completed property development units are classified as inventories in the property development sector, and their worth makes up a large portion of the company's total assets. Property development inventory must be appraised at net realisable value, taking into account future property price fluctuations, which typically involve some subjectivity.

Next, KAMs relating to the valuation of goodwill and intangible assets appeared 207 times among the sample companies. Goodwill attracts auditors' attention as the accounting standards require companies to test goodwill impairment annually. It is difficult to calculate the value of these assets precisely, and the effects on the accounting numbers reported in financial statements may be significant, particularly for sectors with volatile economic conditions (KPMG, 2017). Therefore, it is reasonable to find goodwill and intangible assets valuation included as among the most frequently reported items since auditing these items requires significant audit evidence and judgement.

Investments in subsidiaries, associates, and joint ventures raise the issue of determining whether the carrying values of these investments are impaired. Estimating the recoverable amounts requires considerable judgments and assessments of the invested companies' value in use. The assumptions of future results and cash flow estimates of planned gross profit margins, growth rates, and terminal values, as well as setting a suitable pre-tax discount rate for each invested company, are all part of the value in use calculation. Overall, the top five issues in disclosure of KAMs are the areas of financial reporting that auditors consider most uncertain, and the auditors believe they must disclose significantly more information to shareholders and investors regarding those areas. 
MANAGEMENT AND ACCOUNTING REVIEW, VOLUME 20 NO 3, DECEMBER 2021

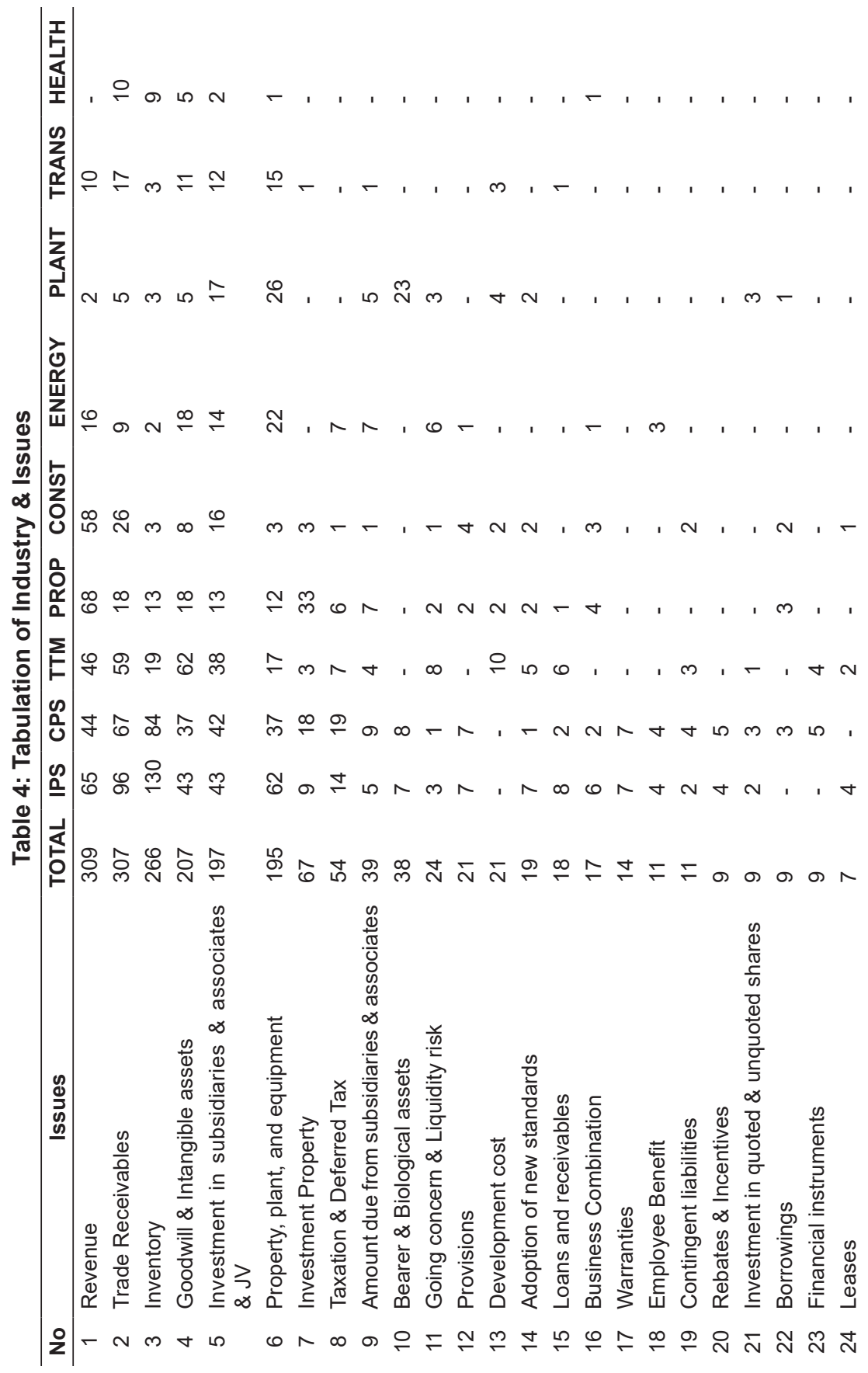




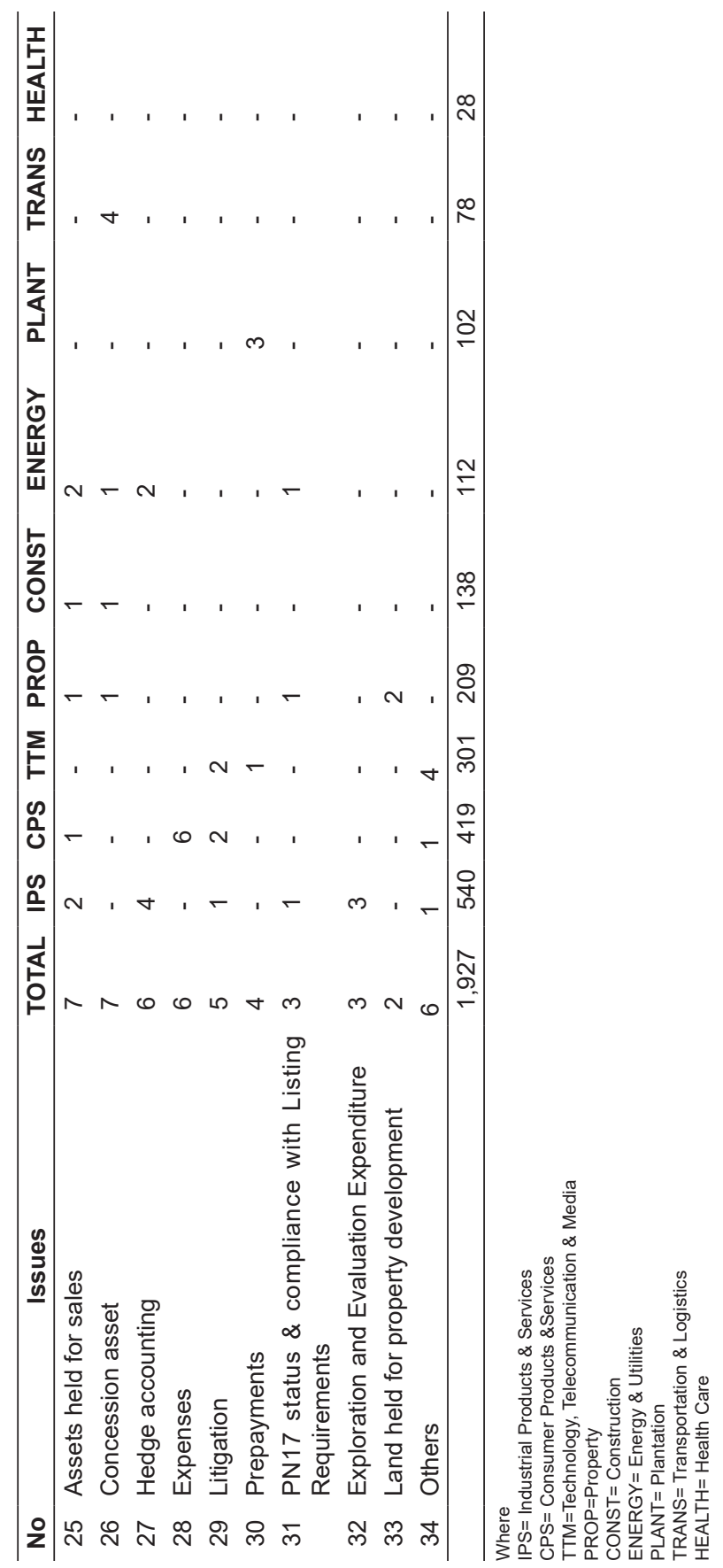


Table 5: Descriptive Statistics

\begin{tabular}{lcccc}
\hline \multicolumn{1}{c}{ Variable } & Mean & Std. Dev. & Min & Max \\
NUM_KAMs & 2.07 & 1.023 & 0 & 6 \\
NEW_KAMs & .9 & 1.067 & 0 & 6 \\
RE_KAMs & 1.166 & 1.088 & 0 & 5 \\
PRICE & .904 & .823 & .115 & 2.69 \\
BVS & 1.364 & 1.85 & -.107 & 15.068 \\
ROE & 2.959 & 9.307 & -14.47 & 16.28 \\
EPS & .03 & 1.148 & -25.07 & 5.15 \\
DPS & .068 & .327 & 0 & 6 \\
DY & 1.624 & 1.658 & 0 & 4.48 \\
PE & 9.609 & 14.115 & -11.95 & 33.43 \\
SIZE & 12.485 & 1.761 & 8.76 & 18.28 \\
LEV & 18.564 & 14.354 & 1.11 & 43.04
\end{tabular}

where: $N U M_{-} K A M s=$ Total number of matters mentioned in KAMs' section; NEW_KAMs= The new matters in the KAMs' section of the current year; $R E K A M s=$ The matters reported in current year and in prior year; $P R I C E=S h a r e$ Price of a company at 4 months after financial year-end; $B V S=$ total shareholders' equity/number of shares outstanding; $R O E=$ Net Income / Shareholders equity; EPS= net income/number of shares outstanding; $D P S=$ dividends paid/number of shares outstanding; $D Y=$ Dividend Per Share/ Price Per Share; $P E=$ Stock price/ EPS; SIZE= Natural log of Market capitalization at the end of the year; $L E V=$ total debt divided by total assets.

The descriptive statistics for all the continuous variables employed in this study are summarised in Table 5. The mean value of the total KAMs, NUM_KAMs, is 2.07 , with a standard deviation of 1.023 . The mean value of $N E W \_K A M s$ is 0.9 (standard deviation of 1.067) and $R E \_K A M$ is 1.166 (standard deviation of 1.088). It meant that on average, the selected companies had two KAMs in their auditor's report, one for new issues and one for recurring or repeated issues. PRICE had a mean of 0.904 , with a maximum of 2.69 and a minimum of 0.115 . The average values of $B V S, R O E$, and $E P S$ were 1.364, 2.959, and 0.03, respectively. DPS had a mean of 0.068 , and $D Y$ had a mean of 1.624. PE, SIZE, and $L E V$ had the respective mean values of $9.609,12.485$, and 18.564. The standard deviations of $R O E, P E$, and $L E V$ in the table indicate wide dispersions because these variables have both negative and positive values, and when working with large volumes of data, wide dispersions are common. To limit the effect of outliers, the variables with extreme values were winsorized at $10 \%$, which means the top 5\% and bottom 5\% were replaced with their next closest value. 
Table 6 shows the correlation between the independent and dependent variables used in the regression model. The table shows that PRICE and SIZE had the highest correlation (Pearson coefficient $=0.694 ; p<0.1$ ). Except for $L E V$, all the control variables had a positive and significant relationship with PRICE. The directions of the association were as predicted and indicated in Table 2. The correlation analysis results also suggested that there was no association between KAMs and PRICE. However, NUM KAMs had a positive association with SIZE (Pearson coefficient $=0.190 ; p<0.1$ ) and $L E V$ (Pearson coefficient $=0.131 ; p<0.1)$. Meanwhile, $N E W \_K A M s$ and $R E \_K A M s$ were only correlated with SIZE (Pearson coefficient $=0.086 ; p$ $<0.1$ and Pearson coefficient $=0.092 ; p<0.1$, respectively). This finding is consistent with Abu and Jaffar (2020) who found that company size had the largest impact on the number of KAMs issued by the auditor. This finding can be explained as large companies are associated with business complexities and unique transactions. The variance inflation factor (VIF) test showed a mean of 5.25, indicating no multicollinearity problem since the mean VIF was less than 10. According to Law (2018), one of the advantages of using panel data is it reduces multicollinearity. 


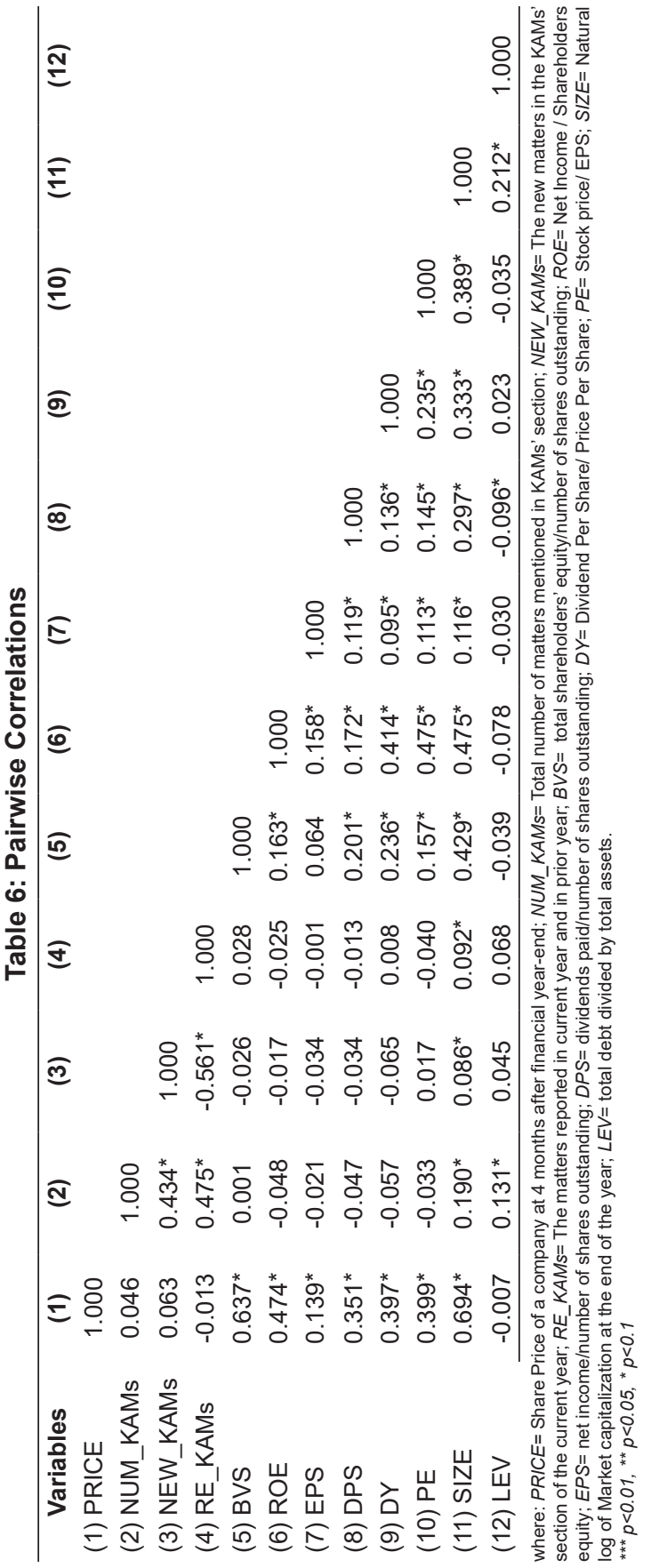


Table 7: The Summary of Estimation Results

\begin{tabular}{|c|c|c|c|}
\hline \multicolumn{4}{|c|}{ Dependent variable - PRICE } \\
\hline Variables & Pooled OLS & Random Effect & Fixed Effect \\
\hline \multirow[t]{2}{*}{ NUM_KAMs } & -0.0582 & 0.00104 & 0.0200 \\
\hline & $(0.0614)$ & $(0.0466)$ & $(0.0482)$ \\
\hline \multirow[t]{2}{*}{ NEW_KAMs } & 0.0658 & -0.0125 & -0.0321 \\
\hline & $(0.0629)$ & $(0.0479)$ & $(0.0497)$ \\
\hline \multirow[t]{2}{*}{ RE_KAMs } & 0.0694 & -0.0227 & -0.0449 \\
\hline & $(0.0631)$ & $(0.0485)$ & $(0.0505)$ \\
\hline \multirow[t]{2}{*}{ BVS } & $0.179^{* \star *}$ & $0.177^{\star \star \star}$ & 0.0790 \\
\hline & $(0.00936)$ & $(0.0151)$ & $(0.0583)$ \\
\hline \multirow[t]{2}{*}{ ROE } & $0.00925^{* * *}$ & 0.000343 & -0.00204 \\
\hline & $(0.00213)$ & $(0.00147)$ & $(0.00153)$ \\
\hline \multirow[t]{2}{*}{ EPS } & 0.0142 & $0.0221^{* *}$ & $0.0234^{* *}$ \\
\hline & $(0.0133)$ & $(0.00944)$ & $(0.00973)$ \\
\hline \multirow[t]{2}{*}{ DPS } & $0.242^{\star \star \star}$ & $0.0840^{*}$ & 0.0122 \\
\hline & $(0.0489)$ & $(0.0447)$ & $(0.0504)$ \\
\hline \multirow[t]{2}{*}{ DY } & $0.0451^{* \star *}$ & $0.0202^{* *}$ & 0.00603 \\
\hline & $(0.0102)$ & $(0.00947)$ & $(0.0108)$ \\
\hline \multirow[t]{2}{*}{$\mathrm{PE}$} & $0.00433^{\star * *}$ & 0.00125 & 0.000558 \\
\hline & $(0.00123)$ & $(0.000826)$ & $(0.000842)$ \\
\hline \multirow[t]{2}{*}{ SIZE } & $0.181^{* \star *}$ & $0.254^{* \star *}$ & $0.302^{\star * *}$ \\
\hline & $(0.0138)$ & $(0.0163)$ & $(0.0263)$ \\
\hline \multirow[t]{2}{*}{ LEV } & $-0.00217^{*}$ & $-0.00269^{* *}$ & -0.00200 \\
\hline & $(0.00112)$ & $(0.00126)$ & $(0.00162)$ \\
\hline \multirow[t]{2}{*}{ BDSIZE } & $-0.0722^{* *}$ & 0.0127 & 0.0392 \\
\hline & $(0.0310)$ & $(0.0291)$ & $(0.0326)$ \\
\hline \multirow[t]{2}{*}{ BDIND } & 0.0430 & -0.0383 & $-0.0694^{* *}$ \\
\hline & $(0.0312)$ & $(0.0298)$ & $(0.0337)$ \\
\hline \multirow[t]{2}{*}{ BIG4 } & 0.0437 & -0.00934 & 0.00588 \\
\hline & $(0.0377)$ & $(0.0483)$ & $(0.0760)$ \\
\hline Year & Included & Included & Included \\
\hline Industry & Included & Included & Included \\
\hline \multirow[t]{2}{*}{ Constant } & $-1.475^{* * *}$ & $-2.188^{* \star *}$ & $-2.732^{* * *}$ \\
\hline & $(0.152)$ & $(0.188)$ & $(0.335)$ \\
\hline Observations & 931 & 931 & 931 \\
\hline R-squared & 0.714 & & 0.367 \\
\hline Number of ID & & 268 & 268 \\
\hline
\end{tabular}

where: $P R I C E=$ Share Price of a company at 4 months after financial year-end; NUM_KAMs= Total number of matters mentioned in KAMs' section; NEW KAMs= The new matters in the KAMs' section of the current year; $R E K A M s=$ The matters reported in current year and in prior year; $B V S=$ total shareholders' equity/number of shares outstanding; $R O E=$ Net Income / Shareholders equity; EPS= net income/number of shares outstanding; $D P S=$ dividends paid/number of shares outstanding; $D Y=$ Dividend Per Share/ Price Per Share; $P E=$ Stock price/ EPS; SIZE= Natural log of Market capitalization at the end of the year; $L E V=$ total debt divided by total assets; $B D S I Z E=1$ if the Number of Board Members Is Within 6-8, 0 Otherwise ; $B D I N D=1$ if the Proportion of Independent Board > 0.5, 0 Otherwise; $B I G 4=1$ if the Company is Audited by Big 4 Audit Firm, 0 Otherwise ; Year= Year Indicator Variables: 2016-2019; Industry= Industry Classification Based on Bursa Malaysia Listing. Standard errors in parentheses ${ }^{* *} p<0.01,{ }^{* *} p<0.05,{ }^{*} p<0.1$ 
The estimation results of pooled OLS (POLS), random effects (RE), and fixed effects (FE) regression are summarised in Table 7 . The regression analysis for POLS which is our basic model, showed an $R^{2}$ value of 0.714 , indicating that the variables studied explain $71 \%$ of the variation in share price in Malaysia. For BVS, ROE, DPS, DY, PE, and SIZE, the regression findings demonstrated a positive influence and significant at the $1 \%$ level. Meanwhile, BDSIZE had a 5\% significance level and $L E V$ had a $10 \%$ significance level. However, the result of Breusch-Pagan Lagrange Multiplier test indicated $p$-value $<0.05$. Hence, the RE model was preferable to POLS. In other words, there were firm-specific effects in the data. However, when compared with the Hausman test, $p$-value $<0.05$. Thus, the FE model was used in this research. The FE result showed a $R 2$ value of 0.367 , indicating that the independent variables explained only $36.7 \%$ of the variation in PRICE. Only EPS, SIZE, and BDIND were significant at $1 \%$ and $5 \%$ levels. All the models, whether POLS, RE, or FE, showed that KAMs had a low likelihood of influencing stock prices. This finding is in line with the previous research by Boonyanet and Promsen (2019) and Gutierrez et al. (2018), who found little indication of the new auditor's report exerting a major impact on investors' reactions. Therefore, the hypothesis proposed for this study was not empirically supported.

\section{Additional Test}

Prior to the revision of the ISA 700, a GCO would have been provided under the heading titled "Emphasis of Matter". However, with the new amendment, a material uncertainty should be highlighted in a separate section under the heading Going Concern. When there is an issue related to going concern, it is not included in the KAMs section of the auditor's report and the requirements relating to the description of KAMs do not apply (ISA 701: Para A8). However, based on the analysis of KAMs issues in Table 4, 24 auditor's reports still mentioned going concern as part of KAMs. The review of the auditing literature found a strong suggestion that market participants value the information communicated via the GCO. Therefore, this study examined the interaction between KAMs and GCO using a dichotomous variable with a value of 1 if a company received a GCO and 0 otherwise. The coefficients for the interaction between KAMs and GCO were insignificant across all regressions, as shown in Table 8, and the $R^{2}$ remained the same as before the interaction. Therefore, this study 
concluded that the interaction between KAMs and GCO did not have a different impact on investors' reactions in Malaysia.

Table 8: The Summary of Estimation Results (Interaction with GCO)

\begin{tabular}{|c|c|c|c|}
\hline \multicolumn{4}{|c|}{ Dependent variable- $P R I C E$} \\
\hline Variables & Pooled OLS & Random Effect & Fixed Effect \\
\hline \multirow[t]{2}{*}{ NUM_KAMs } & -0.0547 & -0.000158 & 0.0160 \\
\hline & $(0.0622)$ & $(0.0470)$ & $(0.0487)$ \\
\hline \multirow[t]{2}{*}{ NEW_KAMs } & 0.0626 & -0.0103 & -0.0272 \\
\hline & $(0.0638)$ & $(0.0483)$ & $(0.0502)$ \\
\hline \multirow[t]{2}{*}{ RE_KAMs } & 0.0656 & -0.0226 & -0.0424 \\
\hline & $(0.0637)$ & $(0.0489)$ & $(0.0509)$ \\
\hline \multirow[t]{2}{*}{ GCO } & 0.0372 & 0.0253 & 0.0314 \\
\hline & $(0.170)$ & $(0.122)$ & $(0.126)$ \\
\hline \multirow[t]{2}{*}{ GCO*.NUM_KAMs } & -0.210 & 0.0628 & 0.194 \\
\hline & $(0.359)$ & $(0.236)$ & $(0.238)$ \\
\hline \multirow[t]{2}{*}{ GCO*NEW_KAMs } & 0.196 & -0.0842 & -0.217 \\
\hline & $(0.367)$ & $(0.242)$ & $(0.245)$ \\
\hline \multirow[t]{2}{*}{ GCO*RE_KAMs } & 0.242 & -0.0453 & -0.181 \\
\hline & $(0.394)$ & $(0.253)$ & $(0.256)$ \\
\hline \multirow[t]{2}{*}{ BVS } & $0.179^{* * *}$ & $0.177^{\star * *}$ & 0.0817 \\
\hline & $(0.00940)$ & $(0.0152)$ & $(0.0585)$ \\
\hline \multirow[t]{2}{*}{ ROE } & $0.00936^{* * *}$ & 0.000336 & -0.00207 \\
\hline & $(0.00215)$ & $(0.00148)$ & $(0.00155)$ \\
\hline \multirow[t]{2}{*}{ EPS } & 0.0141 & $0.0221^{* *}$ & $0.0235^{\star *}$ \\
\hline & $(0.0133)$ & $(0.00945)$ & $(0.00975)$ \\
\hline \multirow[t]{2}{*}{ DPS } & $0.242^{\star * *}$ & $0.0834^{*}$ & 0.0120 \\
\hline & $(0.0490)$ & $(0.0447)$ & $(0.0505)$ \\
\hline \multirow[t]{2}{*}{ DY } & $0.0449^{* * *}$ & $0.0201^{* *}$ & 0.00626 \\
\hline & $(0.0103)$ & $(0.00949)$ & $(0.0108)$ \\
\hline \multirow[t]{2}{*}{ PE } & $0.00438^{* * *}$ & 0.00124 & 0.000528 \\
\hline & $(0.00124)$ & $(0.000830)$ & $(0.000848)$ \\
\hline \multirow[t]{2}{*}{ SIZE } & $0.181^{* * *}$ & $0.255^{\star * *}$ & $0.304^{* * *}$ \\
\hline & $(0.0138)$ & $(0.0163)$ & $(0.0266)$ \\
\hline \multirow[t]{2}{*}{ LEV } & $-0.00216^{*}$ & $-0.00267^{* *}$ & -0.00194 \\
\hline & $(0.00113)$ & $(0.00127)$ & $(0.00163)$ \\
\hline \multirow[t]{2}{*}{ BDSIZE } & $-0.0722^{\star *}$ & 0.0148 & 0.0443 \\
\hline & $(0.0311)$ & $(0.0294)$ & $(0.0331)$ \\
\hline \multirow[t]{2}{*}{ BDIND } & 0.0415 & -0.0398 & $-0.0713^{* *}$ \\
\hline & $(0.0313)$ & (0.0299) & $(0.0338)$ \\
\hline \multirow[t]{2}{*}{ BIG4 } & 0.0436 & -0.00966 & 0.00493 \\
\hline & $(0.0379)$ & $(0.0485)$ & $(0.0762)$ \\
\hline
\end{tabular}




\begin{tabular}{lccc} 
Year & Included & Included & Included \\
Industry & Included & Included & Included \\
Constant & $-1.478^{\star * *}$ & $-2.194^{\star * *}$ & $-2.764^{\star * *}$ \\
& $(0.153)$ & $(0.189)$ & $(0.339)$ \\
Observations & 931 & 931 & 931 \\
R-squared & 0.714 & & 0.368 \\
Number of ID & & 268 & 268 \\
\hline
\end{tabular}

where: $P R I C E=$ Share Price of a company at 4 months after financial year-end; NUM_KAMs= Total number of matters mentioned in KAMs' section; NEW_KAMs= The new matters in the KAMs' section of the current year; RE_KAMs= The matters reported in current year and in prior year; $G C O=1$ if the company received $G C O$ and 0 otherwise; $B V S=$ total shareholders' equity/number of shares outstanding; $R O E=$ Net Income / Shareholders equity; $E P S=$ net income/number of shares outstanding; DPS= dividends paid/number of shares outstanding; $D Y=$ Dividend Per Share/ Price Per Share; $P E=$ Stock price/ EPS; SIZE = Natural log of Market capitalization at the end of the year; $L E V=$ total debt divided by total assets; $B D S I Z E=1$ if the Number of Board Members Is Within 6-8, 0 Otherwise ; $B D I N D=1$ if the Proportion of Independent Board > 0.5, 0 Otherwise; BIG4=1 if the Company is Audited by Big 4 Audit Firm, 0 Otherwise ; Year= Year Indicator Variables: 2016-2019; Industry= Industry Classification Based on Bursa Malaysia Listing. Standard errors in parentheses ${ }^{* \star} p<0.01$, ${ }^{\star *} p<0.05,{ }^{*} p<0.1$.

\section{CONCLUSION}

This study examined the association between KAMs and investors' reactions in Malaysia. KAMs were measured using the number of KAMs and by looking at whether the KAMs issues are new for the current reporting period or recurring from the previous auditor's report. Meanwhile, investors' reactions were gauged using the share prices of companies at four months after each financial year end. Overall, the results revealed that the effect of KAMs on investors' reactions was not evident in Malaysia even though KAMs interacted with the going concern opinion. Share price was influenced mostly by a company's financial performance and governance characteristics rather than by the auditor's report, which is represented by KAMs. The descriptive analysis of KAMs issues showed that the top five issues in disclosure of KAMs are the areas of financial reporting that auditors consider as the most uncertain, and the disclosures of KAMs were mostly related to firms' characteristics such as firm size and leverage.

Following the implementations of KAMs by the IAASB in 2016 and Critical Audit Matters by PCAOB in 2019, studies on the effects of these implementations are emerging. This study adds to the body of knowledge regarding the impact of investors' reactions, particularly in the Malaysian setting. Policymakers, standard setters, and regulators should be curious about how these new enhancements in the auditor's report affect various 
stakeholders worldwide. The outcomes will serve as valuable feedback for future enhancements.

There are certain limitations to this research. First, KAMs were measured in only three ways, and investors' reaction was measured solely in terms of share price, as shown in Table 2. Second, the findings are limited to the Malaysian setting. Hence, future research is suggested to focus on identifying alternative KAMs measurements that could influence investors' reaction. For example, rather than analysing investors' reaction using a quantitative analysis, future research could benefit from a qualitative investigation of how Malaysian investors react to KAMs, which could reveal in-depth information on why and how investors react.

\section{ACKNOWLEDGEMENTS}

The authors gratefully acknowledge the financial support from Faculty Economics and Management, Universiti Kebangsaan Malaysia (UKM) under Geran Inisiatif Penyelidikan (GIP), EP-2020-066.

\section{REFERENCES}

Abad, D., Sánchez-Ballesta, J. P., \& Yagüe, J. (2017). Audit opinions and information asymmetry in the stock market. Accounting and Finance. https://doi.org/10.1111/acfi.12175.

Abu, N. A., \& Jaffar, R. (2020). Audit committee effectiveness and key audit matters. Asian Journal of Accounting and Governance, 14, 1-12. https://doi.org/10.17576/ajag-2020-14-06.

Akerlof, G. A. (1970). The market for lemons: Qualitative uncertainty and the market mechanism. Source: The Quarterly Journal of Economics.

Bédard, J., Gonthier-Besacier, N., \& Schatt, A. (2019). Consequences of expanded audit reports: Evidence from the justifications of assessments in france. Auditing, 38(3), 23-45. https://doi.org/10.2308/ajpt-52339. 
Boonyanet, W., \& Promsen, W. (2019). Key audit matters: Just little informative value to investors in emerging markets? Chulalongkorn Business Review, 41(159), 153-183.

Christensen, B. E., Glover, S. M., \& Wolfe, C. J. (2014). Do critical audit matter paragraphs in the audit report change nonprofessional investors' decision to invest? Auditing, 33(4), 71-94. https://doi.org/10.2308/ ajpt-50793.

Easton, P. D., \& Harris, T. S. (1991). Earnings as an explanatory variable for returns. Journal of Accounting Research, 29(1), 19-36.

Gitman, L.J. (2009). Principles of Managerial Finance. New York: Pearson

Gutierrez, E., Minutti-Meza, M., Tatum, K. W., \& Vulcheva, M. (2018). Consequences of adopting an expanded auditor's report in the United Kingdom. Review of Accounting Studies, 23(4), 1543-1587.

Hay, D., \& Cordery, C. (2018). The value of public sector audit: Literature and history. Journal of Accounting Literature, 40, 1-15. https://doi. org/10.1016/j.acclit.2017.11.001.

Hearn, B. (2013). The determinants of IPO firm prospectus length in Africa. Review of Development Finance, 3(2), 84-98. https://doi.org/10.1016/j. rdf.2013.04.002.

Hsu, J., Young, W., \& Chu, C. H. (2011). Price behavior of qualified companies around the audit report and report announcement days: The case of Taiwan. Journal of International Financial Management and Accounting, 22(2), 114-130. https://doi.org/10.1111/j.1467646X.2011.01047.

IAASB. (2016). ISA 200: Overall Objective of the Independent Auditor and the Conduct of an Audit in Accordance with International Standards on Auditing. https://www.mia.org.my/v2/downloads/handbook/standards/ ISA/2018/03/14/MIA_ISA_200.pdf. 
IAASB. (2018). ISA 701:Communicating Key Audit Matters in The Independent Auditor's Report Auditor's Report. https://www.mia.org. my/v2/downloads/handbook/standards/ISA/2018/08/08/ISA_701.pdf.

Ianniello, G., \& Galloppo, G. (2015). Stock market reaction to auditor opinions - Italian evidence. Managerial Auditing Journal, 30(6/7), 610-631.

Ittonen. (2012). Market reactions to qualified audit reports : research approaches. Accounting Research Journal, Vol. 25(No. 1), 8-24. https:// doi.org/10.1108/10309611211244483.

Kachelmeier, S. J., Rimkus, D., Schmidt, J. J., \& Valentine, K. (2019). The forewarning effect of critical audit matter disclosures involving measurement uncertainty. Contemporary Accounting Research. https:// doi.org/10.1111/1911-3846.12583.

Khan, K.I., Aamir, M., Qayyum, A., Nasir, A. \& Khan, M.I. (2011). Can dividend decisions affect the stock prices: A case of dividend paying companies of KSE. International Research Journal of Finance and Economics, 76(68), pp.69-74.

KPMG. (2017). Key Audit Matters: Auditor's report snapshot 20 September 2017. Available at https:/home.kpmg/au/en/home/insights/2017/09/ key-audit-matters-auditor-report-20-september-2017.html (Accessed: 9 April 2020).

Krejcie, R. \& Morgan, D. (1970) Determining sample size for research activities. Educational and Psychological Measurement, 30, 607-610.

Law, S.H. (2018). Applied panel data analysis: Short panels. University Putra Malaysia Press, Serdang.

Lennox, C. S., Schmidt, J. J., \& Thompson, A. (2015). Is the expanded model of audit reporting informative to investors? evidence from the UK. SSRN Electronic Journal. https://doi.org/10.2139/ssrn.2619785. 
Menon, K., \& Williams, D. D. (2010). Investor reaction to going concern audit reports. The Accounting Review, 85(6), 2075-2105. https://doi. org/10.2308/accr.2010.85.6.2075.

Fayad Altawalbeh, M. A., \& Alhajaya, M. E. S. (2019). The investors reaction to the disclosure of key audit matters: empirical evidence from Jordan. International Business Research, 12(3), 50. https://doi. org/10.5539/ibr.v12n3p50.

Nasir, A.H.M. (2019). Laporan audit luaran di Malaysia: Analisis eksploratori perkara utama audit. Asian Journal of Accounting and Governance, 11 .

Nirmala, P.S., Sanju, P.S. \& Ramachandran, M. (2011). Determinants of share prices in India. Journal of emerging trends in economics and management sciences, 2(2), pp.124-130.

Ohlson, J.A. (1995). Earnings, book values, and dividends in equity valuation. Contemporary accounting research, 11(2), pp.661-687.

Pelzer, J.R.E., (2016). Understanding barriers to critical audit matter effectiveness: A qualitative and experimental approach. FL State University $\mathrm{PhD}$ paper.

Porumb, V.-A., Yasemin, Z., Gerald, L., Reggy, H., \& Dick, D. W. (2018). Is more always better? disclosures in the expanded audit report and their impact on loan contracting. SSRN Electronic Journal. https://doi. org/10.2139/ssrn.3216492.

Rahmat, M.M., Ahmed, K. \& Lobo, G.J. (2020). Related party transactions, value relevance and informativeness of earnings: Evidence from four economies in East Asia. Review of Pacific Basin Financial Markets and Policies, 23(01), p.2050005.

Reid, L. C., Carcello, J. V., Li, C., \& Neal, T. L. (2015). Are auditor and audit committee report changes useful to investors? evidence from the United Kingdom. SSRN Electronic Journal. https://doi.org/10.2139/ ssrn.2637880. 
Securities Commission Malaysia. (2018). Enhanced Auditors' Report - A review of first-year implementation experience in Malaysia. https:// www.sc.com.my/api/documentms/download.ashx?id=450ac242-2fdd4719-bda5-6e0adf128135.

Sekaran, U. \& Bougie, Ro. (2016). Research methods for business: A skill building approach. John Wiley \& Sons.

Sharif, T., Purohit, H. \& Pillai, R. (2015). Analysis of factors affecting share prices: The case of Bahrain stock exchange. International Journal of Economics and Finance, 7(3), pp.207-216.

Tahinakis, P., \& Samarinas, M. (2016). The incremental information content of audit opinion. Journal of Applied Accounting Research , 17(2), 1-28.

Velte, P. (2019). Associations between the financial and industry expertise of audit committee members and key audit matters within related audit reports. Journal of Applied Accounting Research, 21(1), 185-200. https://doi.org/10.1108/JAAR-10-2018-0163.

Velte, P., \& Issa, J. (2019). The impact of key audit matter (KAM) disclosure in audit reports on stakeholders' reactions: a literature review. Problems and Perspectives in Management, 17(3), 323-341. https:// doi.org/10.21511/ppm.17(3).2019.26. 
